\title{
KEPUASAN DAN LOYALITAS KONSUMEN KORPORAT UNTUK ACARA MICE TERHADAP KUALITAS PELAYANAN HOTEL HSTH
}

\author{
Agus Prihanto \\ Manajemen Bisnis Institut Pertanian Bogor \\ Email: agusprihanto63@yahoo.com
}

\begin{abstract}
Abstrak
Pariwisata dan usaha perhotelan semakin berkembang, khususnya acara MICE. Penelitian ini bertujuan menganalisis faktor-faktor kepuasan dan loyalitas konsumen institusional acara MICE di hotel HSTH, menganalisis perbedaan kepuasan dan loyalitas antara Institusi Pemerintah dan Non-pemerintah serta membuat strategi untuk Hotel HSTH. Analisis dilakukan menggunakan Pemodelan Persamaan Struktural, Analisis Kepentingan Performa, Indeks Kepuasan Konsumen dan Indeks Loyalitas Konsumen. Berdasarkan lima dimensi Parasuraman, faktor yang paling penting adalah dimensi tangible. Rekomendasinya adalah memperbaiki semua atribut dimensi tangible dan atribut lainnya, meningkatkan pengetahuan staf hotel dan memonitor program dan supervisi kualitas kerja.
\end{abstract}

Kata kunci: Model persamaan struktural, analisis kepentingan performa, indeks kepuasan konsumen, indeks loyalitas konsumen.

\begin{abstract}
Tourism and Hotel businesses are moving forward, espesially for MICE event. The objectives of this research were to analyze the factors of corporate customer satisfaction and loyalty on MICE event at hotel $H S T H$, the difference of satisfaction and loyalty beetwen governmental and non-governmental institutions, and to form the strategies of Hotel HSTH. It was conducted by using Structural Equation Modelling (SEM), Importance Performance Analysis (IPA), Customer Satisfaction Index (CSI) and Custommer Loyalty Index $(C L I)$. Based on the five dimension of Parasuraman, the most important factor was tangible dimension. The recommendations were: to upgrade all atribute espesially from tangible dimension and other atribute; to increase the knowledge of the hotel staff; and to monitor program and supervisory of the working quality.
\end{abstract}

Keywords: Structural equation modelling (SEM), importance performance analysis (IPA), customer satisfaction index (CSI), custommer loyalty index (CLI).

\section{PENDAHULUAN}

Hotel berkembang menjadi tempat industri MICE (Meeting, Incentive, Conference \& Exhibition). Industri MICE di Bogor juga menunjukan pertumbuhan yang tinggi, dari 70.295 kamar pada tahun 2007 hingga 219.263 kamar pada tahun 2011. Hampir setiap hari kegiatan MICE ini dapat ditemui di hotel atau gedung pertemuan di Bogor. Hal ini dapat terlihat pada Gambar 1.

Petumbuhan permintaan acara MICE ini tidak sejalan dengan target hotel HSTH yang membidik sasarannya pada konsumen Non-pemerintah yang mempunyai daya beli tinggi. Akan tetapi, konsumen institusi Pemerintah menunjukan peningkatan permintaan acara yang cukup tinggi, dengan daya beli yang sudah ditentukan budgetnya, tetapi mempunyai kontribusi acara cukup besar. Pertumbuhan acara konsumen non-pemerintah menunjukkan angka penurunan dari tahun ke tahun, diduga karena kinerja hotel yang menurun, sehingga tingkat penerimaan menjadi kurang optimal seperti terlihat dalam Gambar 2.

Adapun beberapa tujuan penelitian yang ingin dicapai, antara lain: Menganalisis perbedaan tingkat kepuasan dan loyalitas tamu institusi Pemerintah dan Non-pemerintah yang mengadakan acara MICE di Hotel HSTH; Menganalisis faktor-faktor yang mempengaruhi kepuasan dan loyalitas konsumen institusi terhadap pelayanan acara MICE di Hotel HSTH; Merumuskan strategi yang dapat dilakukan Hotel HSTH untuk meningkatkan pelayanan dan memperbaiki kinerja perusahaan terkait pelayanan kepada institusi Pemerintah dan Non-pemerintah. 


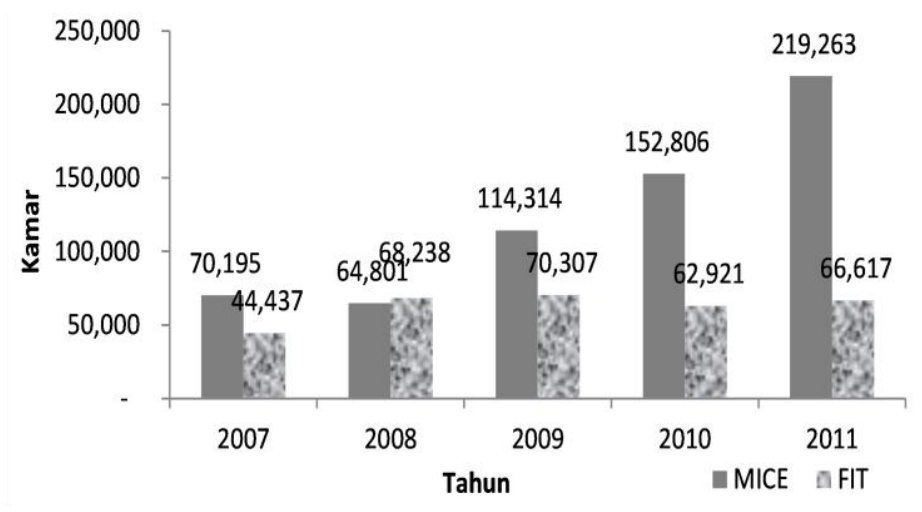

Keterangan: FIT $=$ Free Individual Traveller

\section{Gambar 1. Jumlah Hunian Kamar Hotel di Bogor Tahun 2007-2011}

Sumber: Departemen Marketing dan Promosi Hotel HSTH, 2012

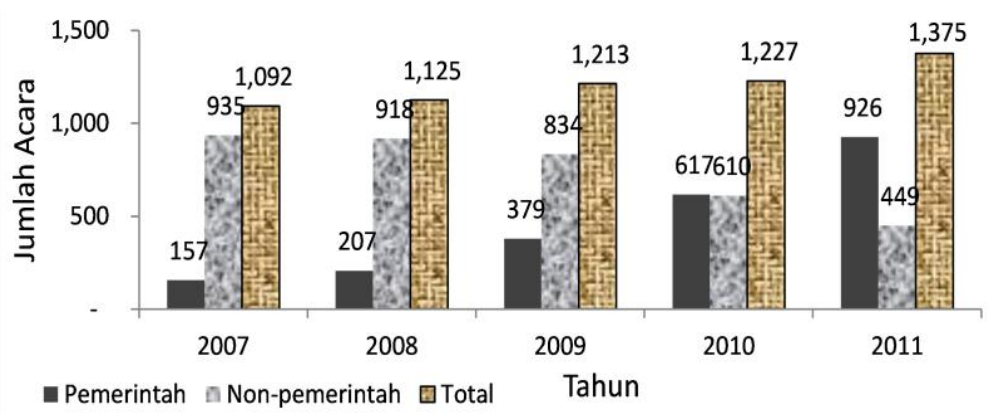

Gambar 2. Grafik Intensitas Acara MICE di Hotel HSTH

Sumber: Departemen Marketing dan Promosi Hotel HSTH, 2012

\section{LANDASAN TEORI DAN HIPOTESIS}

Penelitian tentang dimensi kualitas pelayanan oleh Parasuraman et al. (1985) yang disempurnakan pada tahun 1988 terdiri dari dimensi tangible, reliability, responsiveness, assurance dan empathy, yang dapat mengetahui perbedaan kepentingan dan kinerja suatu jasa pelayanan. Model kualitas jasa pelayanan yang populer dan hingga kini dijadikan banyak acuan dalam riset manajemen dan pemasaran jasa adalah model Service Quality (SERVQUAL).

Castle (2008), dalam disertasinya yang berjudul Comparing Expectations and Perceptions of Service Quality for Special Event Entertainment Services, meneliti kepuasan konsumen yang menggunakan jasa event organizer untuk acara spesial yang bersifat hiburan di Detroit. Dalam penelitian ini menggunakan metode survei kepada konsumen yang mengadakan acara dengan menggunakan instrumen SERVQUAL. Hasil penelitiannya menyatakan meningkatkan kualitas pelayanan dibutuhkan manajemen yang efektif. Manajemen yang efektif mendukung dimensi supply and demand dari kualitas pelayanan.
Chu \& Choi (2000), melakukan penelitian terhadap faktor-faktor yang mempengaruhi kualitas pelayanan hotel di Hong Kong menggunakan konsep Importance Performance Analysis (IPA). Penelitian menganalisis faktor-faktor yang menjadi pertimbangan wisatawan dalam memilih hotel di Hong Kong. Teknik penskalaan yang digunakan adalah skala likert dengan tujuh skala untuk pengukuran kepentingan dan kinerja. Analisis IPA dimanfaatkan untuk membandingkan persepsi wisatawan terhadap faktor yang telah dianalisis sebelumnya. Hasil analisis ini berupa empat kuadran yang menggambarkan kinerja dan kepentingan, ini didapatkan hasil untuk faktor Value masuk dalam kuadran Concentrate Here; Kualitas pelayanan, kamar, penerima tamu dan Keamanan masuk dalam kuadran Keep Up the Good Work; Fasilitas bisnis, Makanan dan minuman masuk dalam kuadran Low Priority.

Markovic (2010), melakukan penelitian tentang pengukuran kepuasan dan loyalitas konsumen hotel. Dikatakan memahami kebutuhan konsumen adalah masalah kritis dari sebuah usaha jasa pelayanan. 
Konsumen yang loyal belum tentu menjadi konsumen yang loyal. Image hotel dan kepuasan konsumen pada reception, housekeeping, food and beverage dan harga sangat berhubungan positif. Penelitian kepuasan dengan menggunakan kuesioner dengan skala Likert dengan skala 1 sangat tidak puas dan skala 7 sangat puas. Penelitian atas loyalitas dilihat dari keinginan untuk membeli kembali dan menyampaikan atau merekomendasikan dengan cara informasi dari mulut ke mulut (word of mouth).

Mengacu pada menurunnya tingkat hunian hotel dari institusi Non-pemerintah, serta untuk menjaga kualitas pelayanan pada institusi Pemerintah, maka dilakukan penelitian mengenai kinerja dan tingkat kepentingan atribut kinerja yang sesuai harapan konsumen. Indikator atribut lima dimensi Parasuraman dikaji terkait dengan tingkat kepuasan dan loyalitas konsumen seperti yang dilakukan Castle (2008), analisis menggunakan Structural Equation Modelling (SEM), kemudian dilakukan analisis Importance Performance Analysis (IPA) untuk mengetahui tingkat prioritas perbaikan dari atribut yang mempengaruhi kepuasan konsumen. Identifikasi kepuasan dan loyalitas dilakukan dengan menggunakan hasil analisis SEM yang signifikan menggunakan Customer Satisfaction Index (CSI) dan Customer Loyalty Index (CLI).

\section{METODE PENELITIAN}

Data primer yang bersifat kuantitatif didapatkan dengan penyebaran kuesioner yang terstruktur (structured questionaire) kepada contact person institusi secara langsung. Jawaban dibuat berdasarkan skala (scale response question), menggunakan teknik skala Likert (1-7) sesuai metode yang digunakan Parasuraman et al. (1988). Distribusi kuesioner dengan penyebaran kuesioner langsung, melalui email atau surat kepada contact person korporasi. Pengambilan responden dilakukan dengan metode sampel acak sederhana (simple random sampling). Jumlah responden dalam penelitian ini dihitung dalam kurun waktu lima tahun dimulai sejak tahun 2007 hingga 2011 adalah sebanyak lima kali jumlah atribut

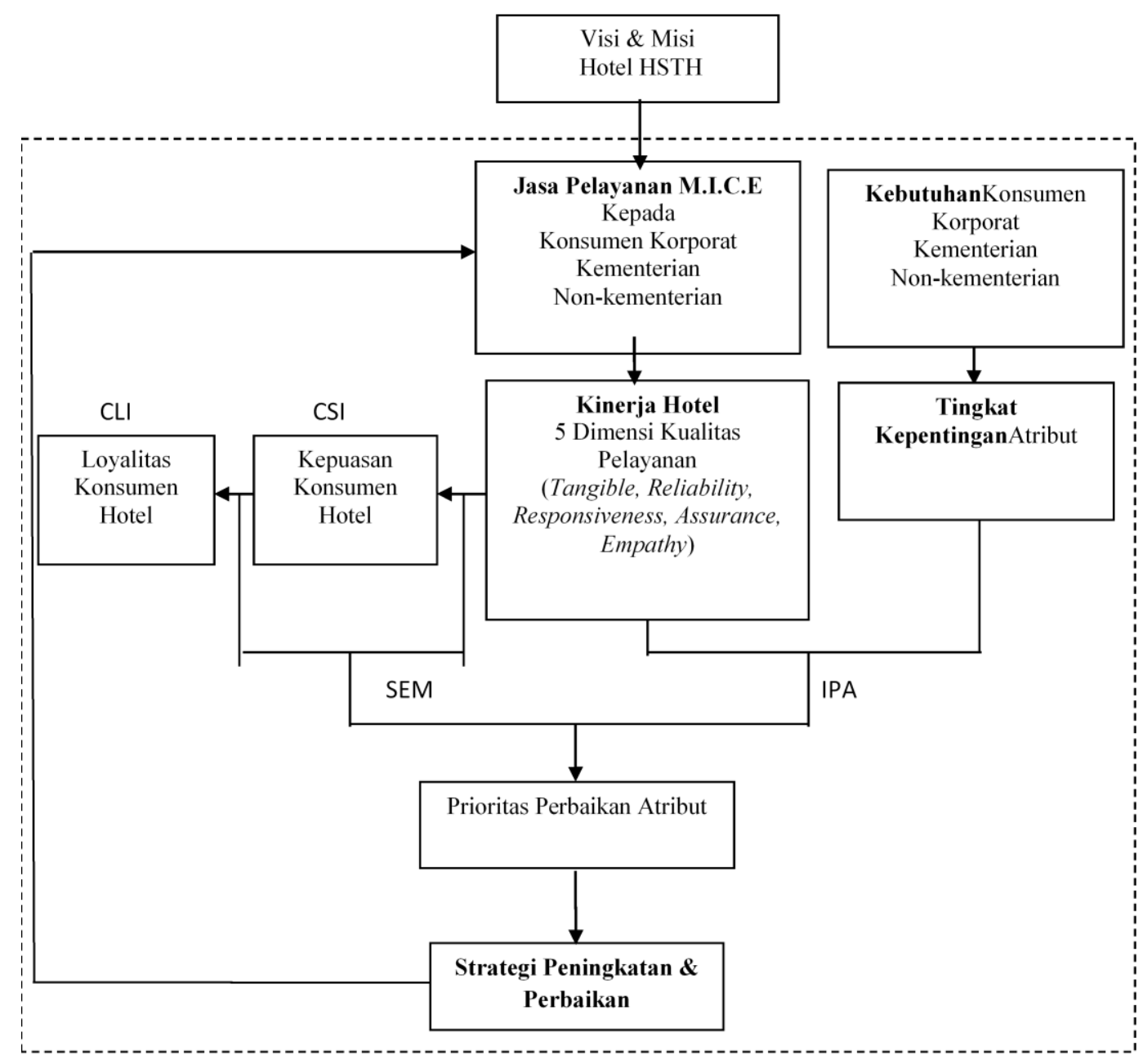

Gambar 3. Kerangka Konseptual Pemikiran 
penelitian (terdapat 21 atribut), sehingga minimal diperlukan masing-masing sebanyak 105 responden dari 6.032 acara institusi yang terbagi menjadi dua sampel responden, yaitu responden institusi Pemerintah sejumlah 2.286 acara dan non-pemerintah sejumlah 3.746 acara.

Konsep operasional penelitian dijabarkan melalui dimensi dan atribut-atribut yang menjadi variabel serta skala pengukuran variabel yang digunakan. Dimensi kualitas pelayanan yang digunakan adalah tangibles, reliability, responsiveness, assurance dan empathy.

Penelitian ini untuk menjelaskan pengaruh dimensi dan komponen-komponen dari kualitas layanan terhadap kepuasan konsumen hotel. Untuk melihat hubungan antar variabel dalam pengukuran ini dapat digunakan pendekatan Structural Equation Modelling, Wijanto (2008). Kemudian dilakukan pengukuran dengan metode Importance Performance Analysis dari Martilla \& James (1977) yang dapat digambarkan dengan diagram kartesius. Sumbu X merepresentasikan tingkat kepuasan yang disebabkan oleh tingkat kinerja dan sumbu Y merepresentasikan tingkat kepentingan atribut.

Kemudian diteliti tingkat kepuasan konsumen, menurut Simamora (2002) skala linier numeric dapat dibuat dengan mencari rentang skala (RS), Menurut Dixon \& Massey (1991) rentang skala yang digunakan dibagi dalam interval mulai dari sangat tidak puas hingga sangat puas. Terakhir dilakukan penelitian tingkat loyalitas, untuk mengukur seberapa besar tingkat loyalitas konsumen. Salah satu cara mengukurnya adalah dengan teknik pembobotan (weighted CSI \& weighted CLI) untuk setiap variabel indikator yang menyusun loyalitas tersebut.

Tabel 1. Nilai Rata-rata Timgkat Kepentingan Atribut dan Kinerja Hotel HSTH

\begin{tabular}{|c|c|c|c|c|c|c|}
\hline \multirow[b]{3}{*}{ No. } & & \multirow[b]{3}{*}{ Atribut } & \multicolumn{2}{|c|}{ Pemerintah } & \multicolumn{2}{|c|}{ Non-pemerintah } \\
\hline & & & MIS & MPS & MIS & MPS \\
\hline & & & $\begin{array}{c}\text { Mean } \\
\text { Importance } \\
\text { Score }\end{array}$ & $\begin{array}{c}\text { Mean } \\
\text { Performance } \\
\text { Score }\end{array}$ & $\begin{array}{c}\text { Mean } \\
\text { Importance } \\
\text { Score } \\
\end{array}$ & $\begin{array}{c}\text { Mean } \\
\text { Performance } \\
\text { Score }\end{array}$ \\
\hline$*$ & \multicolumn{2}{|c|}{ Tangible } & 5,45 & 5,60 & 5,92 & 5,76 \\
\hline 1 & $\mathrm{X} 1$ & $\begin{array}{l}\text { Kualitas kebersihan, kenyamanan dan ketersediaan } \\
\text { perlengkapan ruang rapat }\end{array}$ & 5,35 & 5,54 & 5,87 & 5,71 \\
\hline 2 & $\mathrm{X} 2$ & $\begin{array}{l}\text { Kualitas kebersihan, kenyamanan dan ketersediaan } \\
\text { perlengkapan kamar dan kamar mandi }\end{array}$ & 5,44 & 5,48 & 6,01 & 5,30 \\
\hline 3 & $\mathrm{x} 3$ & $\begin{array}{l}\text { Kualitas penyajian, rasa dan variasi makanan \& } \\
\text { minuman }\end{array}$ & 5,35 & 5,56 & 5,90 & 5,89 \\
\hline 4 & $\mathrm{X} 4$ & Kualitas penampilan dan ketrampilan karyawan & 5,41 & 5,72 & 5,81 & 6,02 \\
\hline 5 & $\mathrm{X} 5$ & Ketersediaaan fasilitas pendukung hotel & 5,26 & 5,58 & 5,84 & 5,66 \\
\hline 6 & $\mathrm{x} 6$ & Lokasi strategis & 5,89 & 5,74 & 6,08 & 6,00 \\
\hline * & \multicolumn{2}{|c|}{ Reliability } & 5,30 & 5,52 & 5,65 & 5,88 \\
\hline 7 & $\mathrm{x} 7$ & Kualitas pelayanan karyawan hotel & 5,46 & 5,54 & 5,95 & 5,52 \\
\hline 8 & $\mathrm{X} 8$ & Harga sesuai dengan fasilitas yang didapat & 5,42 & 5,54 & 5,88 & 5,78 \\
\hline 9 & X9 & Jaminan keamanan dan kenyamanan & 5,35 & 5,58 & 5,86 & 6,19 \\
\hline 10 & $\mathrm{X} 10$ & Ketersediaan internet yang baik & 4,97 & 5,42 & 4,92 & 6,03 \\
\hline$*$ & \multicolumn{2}{|c|}{ Responsiveness } & 5,26 & 5,54 & 5,58 & 6,01 \\
\hline 11 & $\mathrm{X} 11$ & Kualitas ketanggapan karyawan & 5,29 & 5,57 & 5,63 & 6,23 \\
\hline 12 & $\mathrm{X} 12$ & Kecepatan memenuhi permintaan & 5,54 & 5,58 & 5,56 & 5,97 \\
\hline 13 & $\mathrm{X} 13$ & Pengetahuan tentang produk hotel HSTH & 5,11 & 5,45 & 5,56 & 5,85 \\
\hline 14 & $\mathrm{X} 14$ & Kualitas pemecahan masalah & 5,12 & 5,54 & 5,56 & 5,98 \\
\hline$*$ & \multicolumn{2}{|c|}{ Assurance } & 5,39 & 5,68 & 5,81 & 5,89 \\
\hline 15 & X15 & Keramahan dan kesopanan karyawan baik & 5,51 & 5,64 & 6,09 & 5,66 \\
\hline 16 & $\mathrm{X} 16$ & Fasilitas hotel berjalan dengan baik & 5,38 & 5,63 & 5,75 & 6,04 \\
\hline 17 & $\mathrm{X} 17$ & $\begin{array}{l}\text { Hotel berbintang mempunyai kelengkapan fasilitas, } \\
\text { keamanan, kenyamanan yang baik }\end{array}$ & 5,38 & 5,78 & 5,70 & 5,82 \\
\hline 18 & $\mathrm{X} 18$ & Inisiatif karyawan baik & 5,29 & 5,67 & 5,71 & 6,05 \\
\hline * & \multicolumn{2}{|c|}{ Empathy } & 5,21 & 5,64 & 5,82 & 5,90 \\
\hline 19 & X19 & Peka akan keinginan tamu & 5,26 & 5,60 & 5,79 & 5,94 \\
\hline 20 & $\mathrm{X} 20$ & $\begin{array}{l}\text { Tanggap dan menyiapkan kebutuhan tamu sebelum } \\
\text { diminta }\end{array}$ & 5,17 & 5,71 & 5,87 & 5,75 \\
\hline 21 & $X 21$ & $\begin{array}{l}\text { Fleksibilitas karyawan dalam penanganan masalah } \\
\text { tamu }\end{array}$ & 5,21 & 5,62 & 5,79 & 5,99 \\
\hline$*$ & \multicolumn{2}{|c|}{ Average } & 5,34 & 5,60 & 5,77 & 5,88 \\
\hline
\end{tabular}




\section{HASIL PENELITIAN DAN PEMBAHASAN}

Profil responden diuraikan berdasarkan jabatan dan wewenang dalam pengambilan keputusan perusahaan, seperti pimpinan, kepala bagian, panitia acara ataupun orang yang ditunjuk pimpinan sebagai penanggungjawab kelancaran acara.

\section{Tingkat Kepentingan dan Kinerja Hotel}

Pada Tabel 1 berdasarkan nilai tingkat kepentingan atribut dapat dilihat nilai rata-rata jawaban responden institusi Non-pemerintah 5,77 lebih tinggi daripada nilai rata-rata jawaban responden institusi Pemerintah 5,34. Hal ini membuktikan bahwa responden institusi Non-pemerintah mempunyai harapan yang lebih tinggi akan tingkat kualitas pelayanan yang diberikan oleh hotel.

Hasil nilai rata-rata tingkat kinerja responden institusi Non-pemerintah adalah 5,88 yang juga lebih tinggi dari nilai kinerja responden institusi Pemerintah 5,60. Nilai kinerja ini juga menggambarkan bahwa kinerja hotel sudah baik, karena dari kedua jenis responden nilai rata-rata kinerja sudah lebih besar dari nilai ratarata kepentingannya. Walaupun pada data tingkat penggunaan hotel responden institusi Non-pemerintah lebih jarang beracara, tetapi dalam penilaian kinerja memberikan nilai yang lebih baik daripada responden institusi Pemerintah.

\section{Analisis Pengaruh Atribut terhadap Kepuasan}

Uji kecocokan model mengunakan program LISREL 8.30 pada responden institusi hotel HSTH baik Pemerintah maupun Non-pemerintah berdasarkan Goodness of Fit Index (GOF) menunjukkan bahwa model yang dikembangkan semuanya cocok atau dapat diterima.

Analisis dilanjutkan dengan uji persamaan struktural dengancara melihat nilai $\mathrm{t}$ dari setiap koefisien persamaan. Nilai $\alpha$ yang digunakan pada penelitian ini adalah 0,05 atau menggunakan selang kepercayaan $95 \%$, sehingga nilai t minimum yang signifikan adalah 1,96, maka akan didapatkan nilai signifikansi indikator-indikator dalam mempengaruhi variable eksogen ataupun nilai signifikansi variabel eksogen dalam mempengaruhi variabel endogen, serta nilai signifikansi masing-masing variabel endogen. Gambar 4 dan Gambar 6 menunjukkan nilai statistik $\mathrm{t}$ dari model struktural penelitian, sedangkan Gambar 5 dan Gambar 7 menunjukkan hasil estimasi faktor muatan (loading factor) dari model struktural penelitian. Nilai faktor muatan tersebut menunjukkan besar kontribusi setiap variabel indikator terhadap perubah latennya.

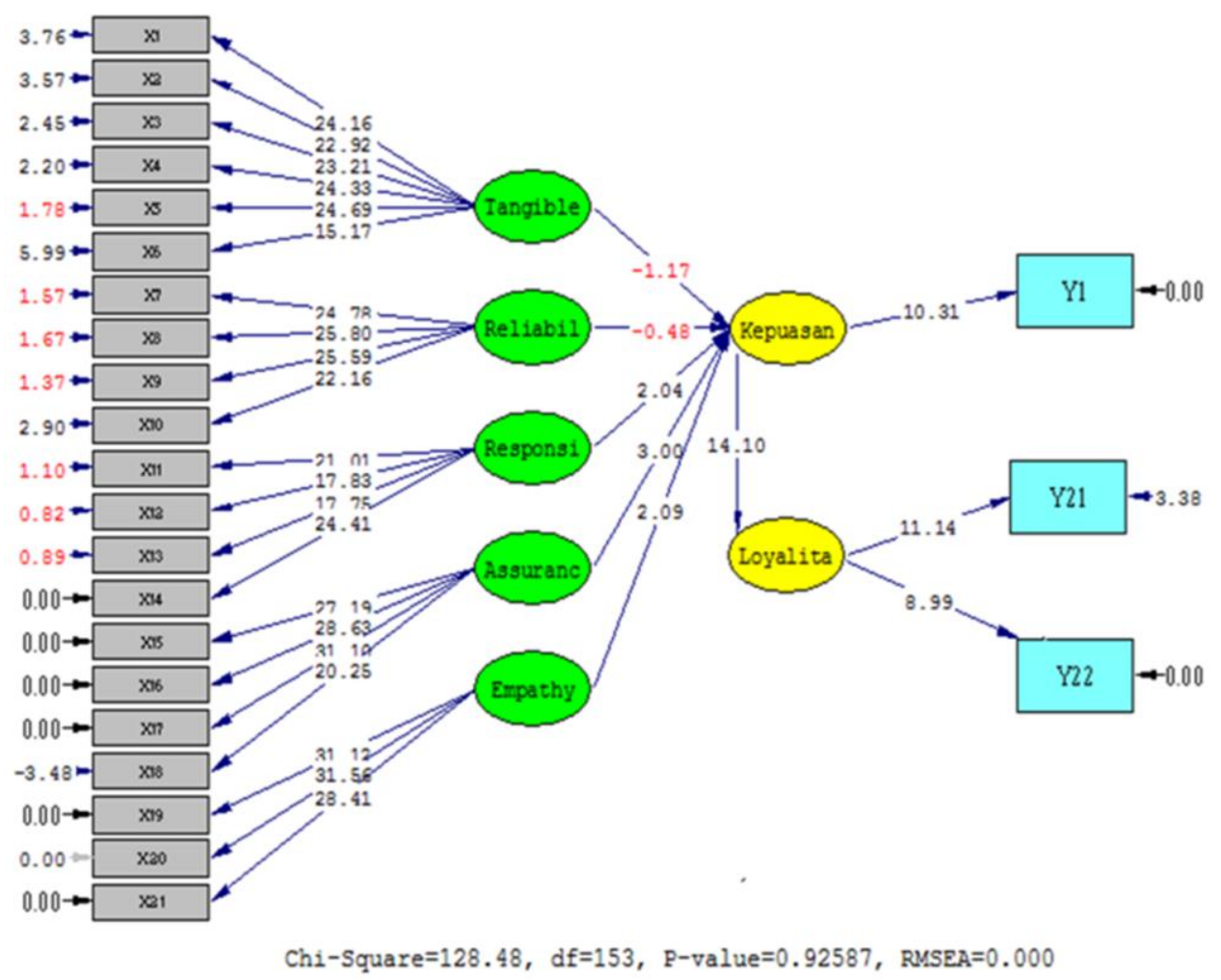

Gambar 4. Path Diagram nilai t institusi pemerintah 


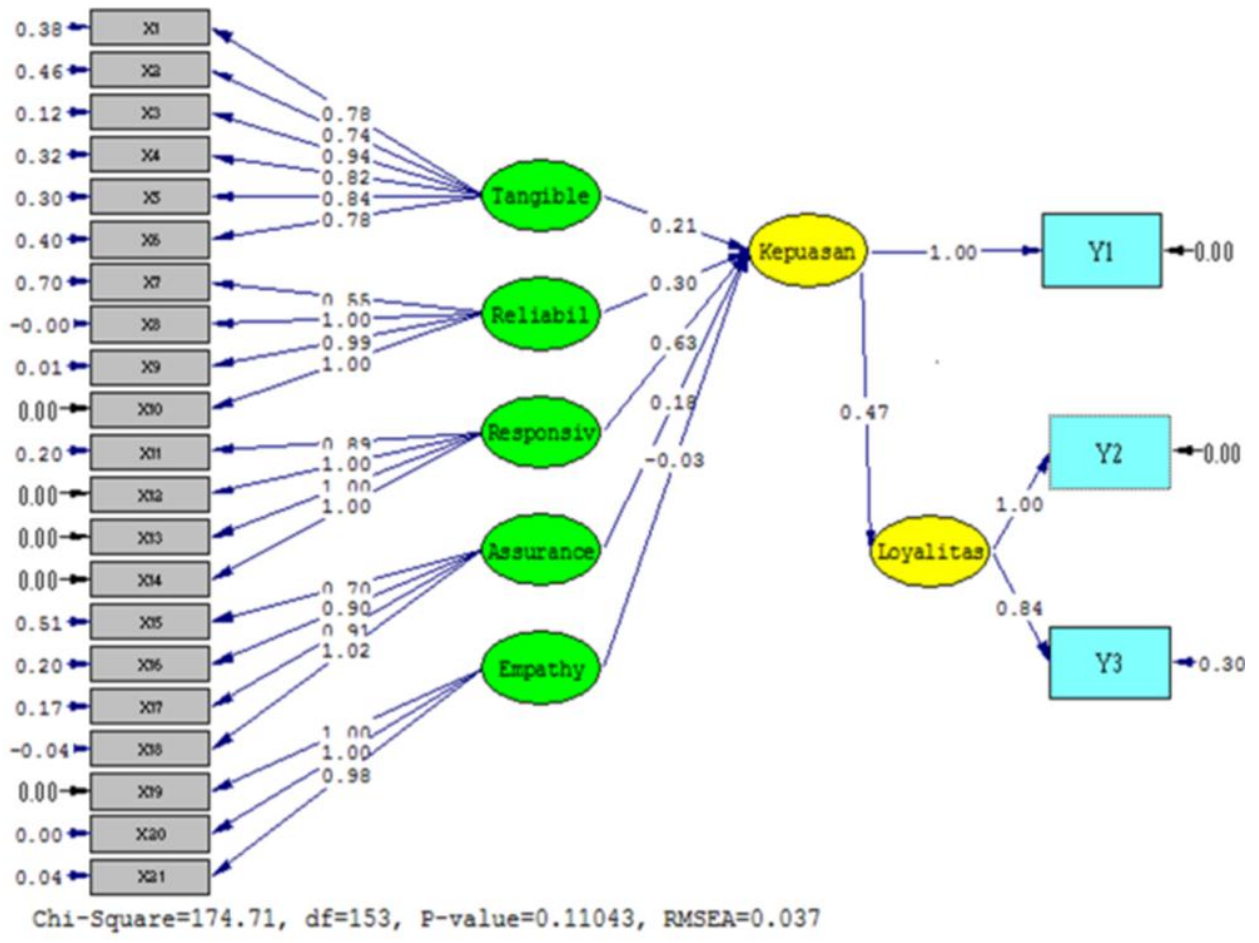

Gambar 5. Path Diagram hasil estimation factor muatan institusi pemerintah

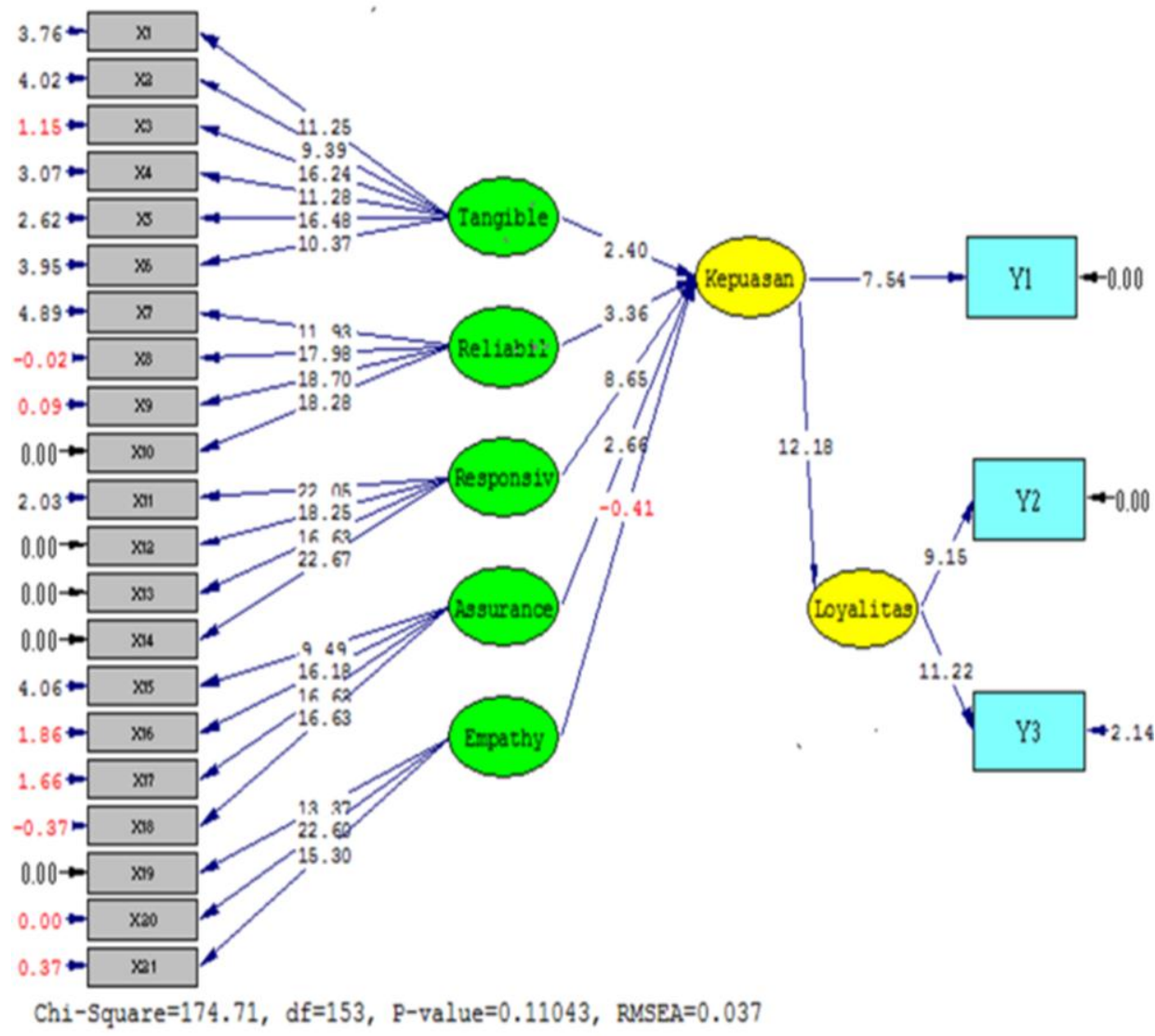

Gambar 6. Path Diagram nilai t institusi Non-pemerintah 


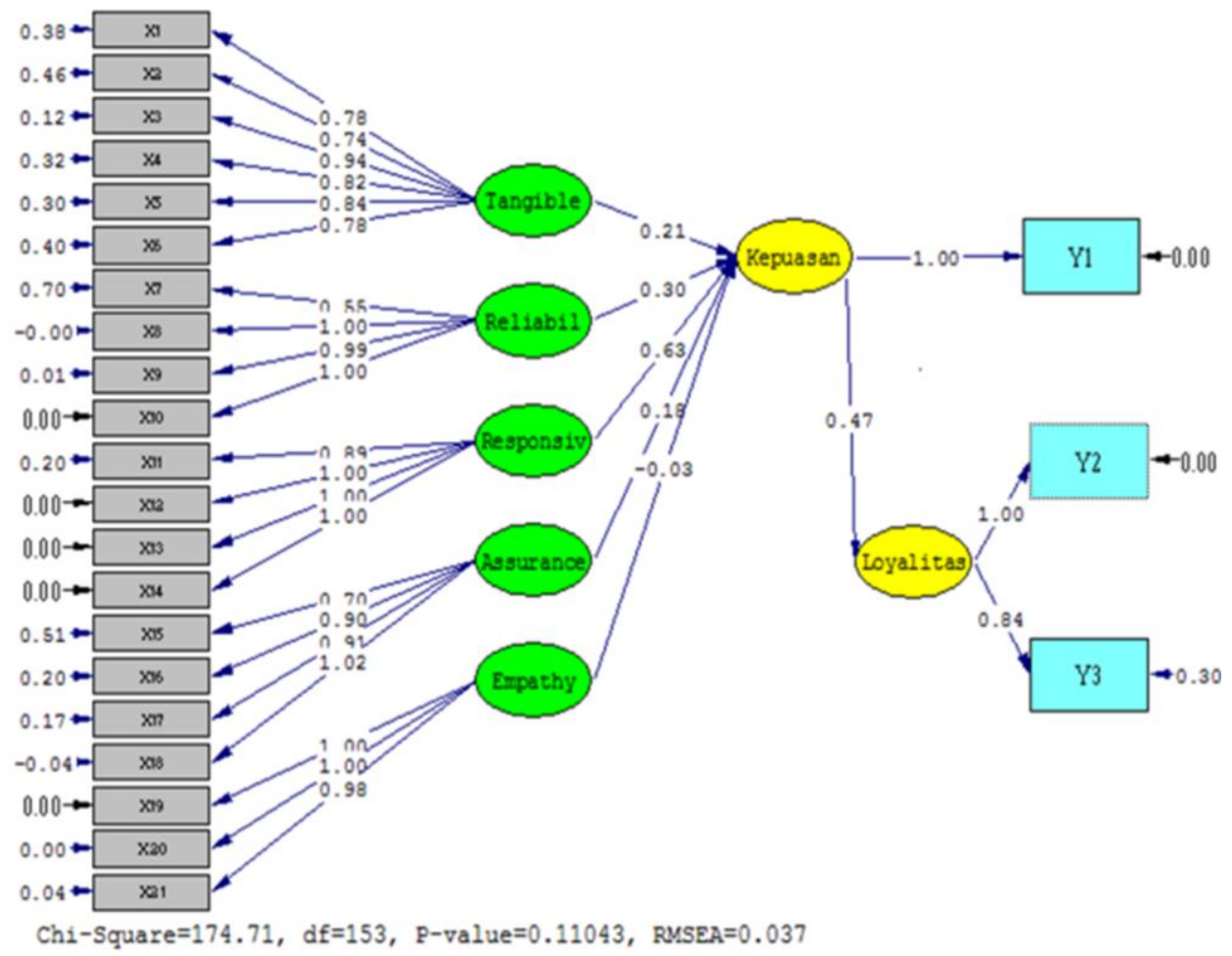

Gambar 7. Path Diagram hasil estimasi faktor muatan institusi Non-pemerintah

\section{Pengaruh Lima Dimensi Kepuasan terhadap Kepuasan dan Loyalitas}

Konsep dasar kepuasan pada model yang dikembangkan dalam penelitian ini adalah variabel laten yang carapengukurannya dihubungkan dengan lima dimensi Parasuraman yang memiliki atribut yang dapat diukur, yaitu: dimensi tangible, reliability, responsiveness, assurance dan empathy.

Hasil nilai faktor muatan seperti terlihat pada Tabel 2, pertama adalah hubungan antara dimensi tangible dengan komponen-komponen pembentukannya dilihat institusi Pemerintah lebih mengutamakan ketersediaaan fasilitas pendukung hotel, sedangkan konsumen institusi non-pemerintah seperti yang dinyatakan Markovic (2010) lebih mengutamakan kualitas penyajian, rasa dan variasi makanan dan minuman, tetapi ketersediaaan fasilitas pendukung hotel yang menduduki posisi kedua. Kedua adalah hubungan antara dimensi reliability dengan komponen-komponen pembentukannya dapat dilihat perbedaan kepentingan yang terjadi pada dimensi reliability adalah institusi pemerintah lebih mengutamakan kualitas layanan karyawan, sedangkan institusi non-pemerintah lebih mengutamakan ketersediaan internet yang baik. Harga menjadi pertimbangan kedua konsumen. Jaminan keamanan dan kenyamanan juga merupakan hal yang menjadi pertimbangan semua institusi. Ketiga yaitu hubungan antara dimensi responsiveness dengan komponenkomponen pembentukannya yaitu semua sampel yang termasuk dalam penelitian ini mempunyai tingkat kepentingan yang sama atas dimensi responsiveness. Hanya besaran nilai yang sedikit berbeda. Atribut tersebut harus dijaga kinerjanya oleh manajemen hotel agar tetap memberikan kepuasan kepada semua institusi. Kecepatan, ketepatan dan kepandaian menjadi hal yang sangat mendukung usaha jasa perhotelan. Keempat adalah hubungan antara dimensi assurance dengan komponen-komponen pembentukannyadapat dilihat seluruhnya memberikan pengaruh signifikan terhadap dimensi assurance. Atribut yang memberikan kontribusi faktor muatan paling besar adalah inisiatif karyawan yang baik dengan nilai 1,30 dan atribut berikutnya mempunyai nilai faktor muatan yang sama seperti institusi pemerintah sebesar 1,00 adalah keramahan dan kesopanan karyawan baik, fasilitas hotel berjalan dengan baik dan hotel berbintang mempunyai kelengkapan fasilitas, keamanan, kenyamanan yang baik. Kelima adalah hubungan antara dimensi empathy dengan komponen-komponen pembentukannya dengan hasil karyawan yang tanggap dan peka adalah hal yang diinginkan konsumen kepada jasa pelayanan hotel. 
Tabel 2. Hasil Nilai Faktor Muatan dan $t$ Hitung Dimensi Kepuasan

\begin{tabular}{|c|c|c|c|c|}
\hline \multirow[b]{2}{*}{ Dimensi / Atribut Dimensi } & \multicolumn{2}{|c|}{ Pemerintah } & \multicolumn{2}{|c|}{ Non-pemerintah } \\
\hline & $\begin{array}{l}\text { Faktor } \\
\text { Muatan }\end{array}$ & $\begin{array}{l}\text { t-hitung } \\
\alpha=0,05\end{array}$ & $\begin{array}{l}\text { Faktor } \\
\text { Muatan }\end{array}$ & $\begin{array}{l}\text { t-hitung } \\
\alpha=0,05\end{array}$ \\
\hline Tangible & -0.17 & -1.17 & 0.21 & 2.40 \\
\hline $\begin{array}{l}\text { Kualitas kebersihan, kenyamanan dan ketersediaan perlengkapan ruang } \\
\operatorname{rapat}(\mathrm{X} 1)\end{array}$ & 0.73 & 24.16 & 0,78 & 11.25 \\
\hline $\begin{array}{l}\text { Kualitas kebersihan, kenyamanan dan ketersediaan perlengkapan kamar } \\
\text { dan kamar mandi (X2) }\end{array}$ & 0.74 & 22.92 & 0,74 & 9.39 \\
\hline Kualitas penyajian, rasa dan variasi makanan \& minuman (X3) & 0.82 & 23.21 & 0,94 & 16.24 \\
\hline Kualitas penampilan dan ketrampilan karyawan $(\mathrm{X} 4)$ & 0.84 & 24.33 & 0,82 & 11.28 \\
\hline Ketersediaaan fasilitas pendukung hotel(X5) & 0.87 & 24.69 & 0,84 & 16.48 \\
\hline Lokasi strategis(X6) & 0.52 & 15.17 & 0,78 & 10.37 \\
\hline Reliability & -0.06 & -0.48 & 0.30 & 3.36 \\
\hline Kualitas pelayanan karyawan hotel (X7) & 0.89 & 24.78 & 0.55 & 11.93 \\
\hline Harga sesuai dengan fasilitas yang didapat (X8) & 0.89 & 25.80 & 1.00 & 17.98 \\
\hline Jaminan keamanan dan kenyamanan (X9) & 0.91 & 25.59 & 0.99 & 18.70 \\
\hline Ketersediaan internet yang baik (X10) & 0.80 & 22.16 & 1.00 & 18.28 \\
\hline Responsiveness & 0.36 & 2.04 & 0,63 & 8.65 \\
\hline Kualitas ketanggapan karyawan (X11) & 0.92 & 21.01 & 0.89 & 22.05 \\
\hline Kecepatan memenuhi permintaan (X12) & 0.94 & 17.83 & 1.00 & 18.25 \\
\hline Pengetahuan tentang produk hotel HSTH (X13) & 0.93 & 17.75 & 1.00 & 16.63 \\
\hline Kualitas pemecahan masalah (X14) & 1.00 & 24.41 & 1.00 & 22.67 \\
\hline Assurance & 0.27 & 3.00 & 0.18 & 2.66 \\
\hline Keramahan dan kesopanan karyawan baik (X15) & 1.00 & 27.19 & 0.70 & 9.49 \\
\hline Fasilitas hotel berjalan dengan baik (X16) & 1.00 & 28.63 & 0.90 & 16.18 \\
\hline $\begin{array}{l}\text { Hotel berbintang mempunyai kelengkapan fasilitas, keamanan, } \\
\text { kenyamanan yang baik (X17) }\end{array}$ & 1.00 & 31.18 & 0.91 & 16.63 \\
\hline Inisiatif karyawan baik (X18) & 1.30 & 20.25 & 1.02 & 16.63 \\
\hline Empathy & 0.40 & 2.09 & -0.03 & -0.41 \\
\hline Peka akan keinginan tamu (X19) & 1.00 & 31.12 & 1.00 & 13.37 \\
\hline Tanggap dan menyiapkan kebutuhan tamu sebelum diminta (X20) & 0.95 & 31.56 & 1.00 & 22.60 \\
\hline Fleksibilitas karyawan dalam penanganan masalah tamu (X21) & 1.00 & 28.41 & 0.98 & 15.30 \\
\hline
\end{tabular}

Hubungan kepuasan dengan komponen kepuasan dalam penelitian ini digunakan satu variabel pengamatan $\mathrm{Y}$ yaitu kepuasan secara keseluruhan (overall satisfaction). Atribut ini pada semua institusi memilki nilai t yang signifikan pada taraf $\alpha=0,05$ artinya atribut ini berpengaruh nyata terhadap variabel laten kepuasan. Hubungan antara dimensi Kepuasan dengan kepuasan, terlihat jelas perbedaan kepentingan dari institusi Pemerintah dan Non-pemerintah akan dimensi yang mempengaruhi kepuasan mereka. Kesamaan yang diharapkan dapat berpengaruh pada kepuasan adalah responsiveness dan assurance. Hubungan antara atribut dimensi kepuasan yang signifikan dengan kepuasan adalah semua atribut dimensi kepuasan yang signifikan harus diprioritaskan untuk menjadi perhatian manajemen hotel dalam membuat perencanaan kerja dan memberikan layanan yang terbaik. Dengan terpenuhi kepentingan atribut sesuai harapan konsumen berarti dapat memberikan kepuasan pada konsumen yang berdampak positif menjadikan konsumen lebih loyal. Dari semua atribut tersebut yang berpengaruh pada kepuasan institusi Pemerintah dan Non-pemerintah perbedaannya adalah hanya pada tingkat kepentingan atributnya, tetapi dimensi responsiveness dan assurance menjadi hal yang paling penting bagi semua institusi.

Pengaruh kepuasan terhadap loyalitas pada institusi Pemerintah nilai uji t adalah 14,10. Pengaruh kepuasan pada institusi Non-pemerintah nilai uji $t$ adalah 12,18. Semua hasil berpengaruh signifikan pada variabel laten loyalitas, karena semuanya nilai $\mathrm{t}$ hitung lebih dari 1,96 $(\alpha=0,05)$. Hubungan dimensi loyalitas dengan komponen loyalitas adalah variabel laten loyalitas untuk institusi Pemerintah dan Nonpemerintah semuanya signifikan berpengaruh dengan nilai t lebih dari 1,96, maka dapat disimpulkan bahwa berdasarkan hitungan statistik atribut loyalitas secara signifikan berpengaruh terhadap variabel laten loyalitas, seperti terlihat pada Tabel 3 . 
Tabel 3. Kontribusi Atribut Loyalitas Terhadap Loyalitas Konsumen Hotel HSTH

\begin{tabular}{lcccc}
\hline \multirow{1}{*}{ Loyalitas } & \multicolumn{2}{c}{ Pemerintah } & \multicolumn{2}{c}{ Non-pemerintah } \\
\cline { 2 - 5 } & $\begin{array}{c}\text { Faktor } \\
\text { Muatan }\end{array}$ & $\begin{array}{c}\text { t-hitung } \\
\alpha=0,05\end{array}$ & $\begin{array}{c}\text { Faktor } \\
\text { Muatan }\end{array}$ & $\begin{array}{c}\text { t-hitung } \\
\alpha=0,05\end{array}$ \\
\hline $\begin{array}{l}\text { Bersedia menggunakan jasa layanan MICE hotel HSTH } \\
\text { kedepannya (P19) }\end{array}$ & 0.73 & 11.14 & 1.00 & 9.15 \\
$\begin{array}{l}\text { Bersedia merekomendasikan jasa layanan MICE hotel HSTH } \\
\text { kepada kolega (P20) }\end{array}$ & 1.00 & 8.99 & 0.84 & 11.22 \\
\hline
\end{tabular}

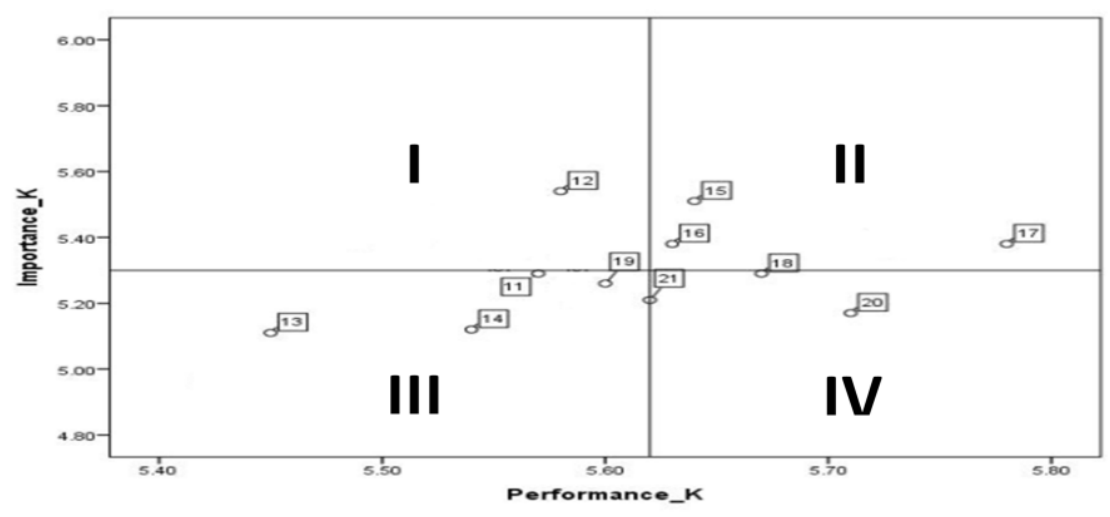

Gambar 8. Diagram Kartesius Institusi Pemerintah

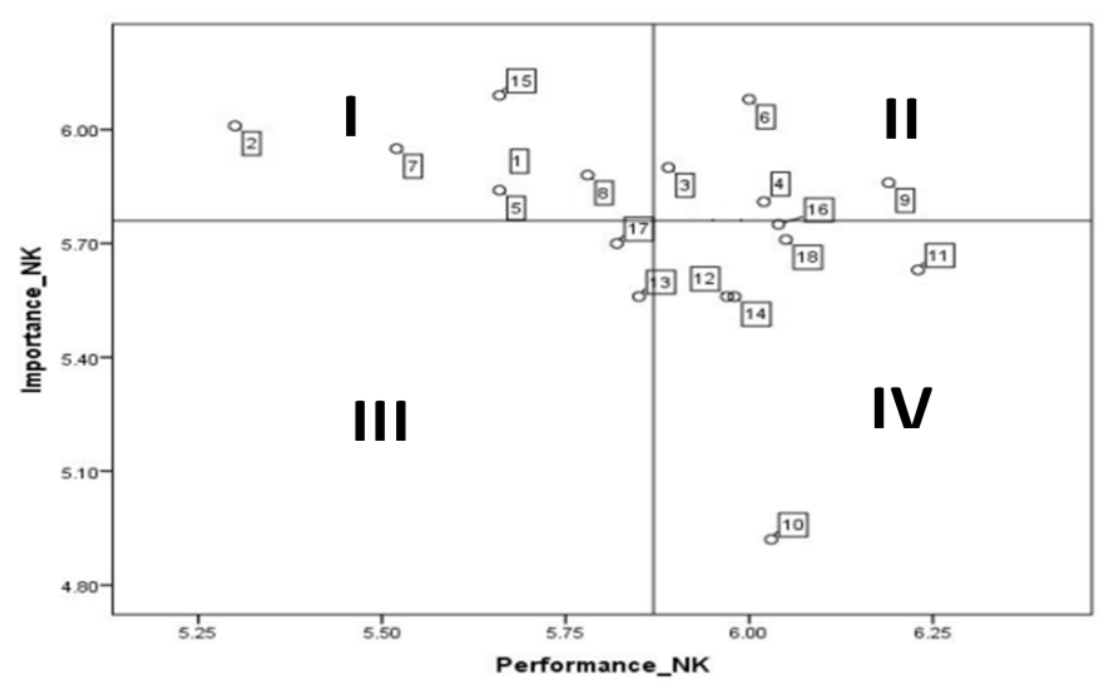

Gambar 9. Diagram Kartesius Institusi Non-pemerintah

Hasil analisis IPA untuk institusi Pemerintah, terlihat pada Gambar 8, bahwa atribut yang dianalisis tersebar menjadi empat bagian yang dibatasi oleh satu garis vertikal dan satu garis horizontal yang saling berpotongan. Garis batas pada sumbu X adalah sebesar 5,60 sedangkan garis batas pada sumbu $\mathrm{Y}$ adalah sebesar 5,34. Hasil untuk institusi Nonpemerintah pada Gambar 9, terlihat bahwa atribut yang dianalisis tersebar pada garis batas pada sumbu $\mathrm{X}$ adalah sebesar 5,88. Garis batas pada sumbu $\mathrm{Y}$ adalah sebesar 5,77.
Pada Tabel 4, kuadran I yang menjadi prioritas utama tingkat kepentingannya, pada institusi Pemerintah terdapat satu atribut dan institusi Nonpemerintah ada enam atribut yang menjadi prioritas utama yang semua berbeda. Manajemen dapat mengidentifikasikan dengan baik prioritas mana yang diharapkan oleh institusi Pemerintah dan Nonpemerintah, sehingga saat memberikan pelayanan dapat dilakukan dengan tepat sesuai jenis konsumennya. Atribut yang termasuk dalam kuadran II yang merupakan kuadran pertahankan prestasi, 
yaitu terdapat sejumlah tiga atribut pada institusi Pemerintah dan empat atribut pada Non-pemerintah yang harus dipertahankan prestasinya oleh manajemen hotel. Atribut yang masuk dalam kuadran III yang merupakan prioritas rendah adalah pada institusi Pemerintah ada tiga dan Non-pemerintah ada empat, hanya satu atribut yang sama. Walaupun demikian manajemen hotel dapat memberikan layanan pada atribut yang masuk dalam kuadran III ini sama baiknya dengan atribut lainnya, karena semuanya mempunyai kontribusi pada pengaruh dimensi kepuasan. Atribut-atribut pelayanan yang termasuk kuadran IV yang dianggap berlebihan kinerjanya. Akan tetapi, tetap harus dijaga walaupun menjadi prioritas yang rendah. Atribut yang masuk dalam kuadran ini hampir semua berbeda antara Pemerintah dan Non-pemerintah, hanya satu atribut yang sama adalah pengetahuan tentang produk hotel. Manajemen dapat membedakan dengan baik dalam memberikan layanan bagi kedua institusi, sehingga pelayanan yang diberikan lebih tepat dan sesuai kebutuhan mereka.

\section{Tingkat Kepuasan dan Loyalitas Responden}

Berdasarkan perhitungan yang terjadi dari atribut yang berpengaruh siginifikan pada analisis SEM, maka diukur CSI kualitas kinerja dan tingkat kepentingan (Eboli \& Mazzulla, 2009), nilai indeks kepuasan institusi Pemerintah sebesar 80,29\%, menurut kelas intervalnya yang terbagi menjadi tujuh masuk dalam range $74,18 \%$ - 86,73\% termasuk dalam kategori puas. Institusi Non-pemerintah ternyata nilai indeks kepuasannyalebih tinggi, sebesar $84,19 \%$ juga termasuk dalam kategori puas.

Keseluruhan atribut dimensi yang secara signifikan berpengaruh pada loyalitas dijadikan dasar perhitungan untuk indeks loyalitas konsumen. Perhitungannya didasarkan pada bobot yang dihitung dari faktor muatan masing-masing atribut pada model SEM dan rata-rata nilai dari masing-masing atribut. Menurut kelas intervalnya maka CLI institusi Pemerintah sebesar $83,21 \%$ dalam interval $80 \%$ $100 \%$ (skala 5), termasuk dalam kategori loyal dan nilai CLI institusi Non-pemerintah sebesar 83,50\%, juga termasuk dalam kategori loyal.

Tabel 4. Atribut yang Termasuk dalam Keempat Kuadran

\begin{tabular}{|c|c|c|c|}
\hline Atribut Kuadran I & & Pemerintah & Non-pemerintah \\
\hline Kualitas kebersihan, kenyamanan dan ketersediaan perlengkapan ruang rapat & $\mathrm{X} 1$ & & $\mathrm{~V}$ \\
\hline $\begin{array}{l}\text { Kualitas kebersihan, kenyamanan dan ketersediaan perlengkapan kamar dan } \\
\text { kamar mandi }\end{array}$ & $\mathrm{X} 2$ & & $\mathrm{~V}$ \\
\hline Ketersediaaan fasilitas pendukung hotel & $\mathrm{X} 5$ & & $\mathrm{~V}$ \\
\hline Kualitas pelayanan karyawan hotel & $\mathrm{X} 7$ & & $\mathrm{~V}$ \\
\hline Harga sesuai dengan fasilitas yang didapat & $\mathrm{X} 8$ & & $\mathrm{~V}$ \\
\hline Kecepatan memenuhi permintaan & $\mathrm{X} 12$ & $\mathrm{~V}$ & \\
\hline Keramahan dan kesopanan karyawan baik & $\mathrm{X} 15$ & & $\mathrm{~V}$ \\
\hline Atribut Kuadaran II & & Pemerintah & Non-pemerintah \\
\hline Kualitas penyajian, rasa dan variasi makanan \& minuman & $\mathrm{X} 3$ & & $\mathrm{~V}$ \\
\hline Kualitas penampilan dan ketrampilan karyawan & $\mathrm{X} 4$ & & $\mathrm{~V}$ \\
\hline Lokasi strategis & X6 & & $\mathrm{V}$ \\
\hline Jaminan keamanan dan kenyamanan & X9 & & $\mathrm{V}$ \\
\hline Keramahan dan kesopanan karyawan baik & $\mathrm{X} 15$ & $\mathrm{v}$ & \\
\hline Fasilitas hotel berjalan dengan baik & $\mathrm{X} 16$ & $\mathrm{v}$ & \\
\hline $\begin{array}{l}\text { Hotel berbintang mempunyai kelengkapan fasilitas, keamanan, kenyamanan } \\
\text { yang baik }\end{array}$ & $\mathrm{X} 17$ & $\mathrm{v}$ & \\
\hline Atribut Kuadran III & & Pemerintah & Non-pemerintah \\
\hline Ketersediaan internet yang baik & $\mathrm{X} 10$ & & $\mathrm{~V}$ \\
\hline Kualitas ketanggapan karyawan & $\mathrm{X} 11$ & & $\mathrm{~V}$ \\
\hline Kecepatan memenuhi permintaan & $\mathrm{X} 12$ & & $\mathrm{~V}$ \\
\hline Kualitas pemecahan masalah & $\mathrm{X} 14$ & & $\mathrm{~V}$ \\
\hline Fasilitas hotel berjalan dengan baik & $\mathrm{X} 16$ & & $\mathrm{~V}$ \\
\hline Inisiatif karyawan baik & $\mathrm{X} 18$ & $\mathrm{~V}$ & $\mathrm{~V}$ \\
\hline Tanggap dan menyiapkan kebutuhan tamu sebelum diminta & $\mathrm{X} 20$ & $\mathrm{~V}$ & \\
\hline Fleksibilitas karyawan dalam penanganan masalah tamu & $\mathrm{X} 21$ & $\mathrm{~V}$ & \\
\hline Atribut Kuadran IV & & Pemerintah & Non-pemerintah \\
\hline Kualitas ketanggapan karyawan & $\mathrm{X} 11$ & $\mathrm{~V}$ & \\
\hline Pengetahuan tentang produk hotel HSTH & $\mathrm{X} 13$ & $\mathrm{v}$ & $\mathrm{V}$ \\
\hline Kualitas pemecahan masalah & X14 & $\mathrm{v}$ & \\
\hline $\begin{array}{l}\text { Hotel berbintang mempunyai kelengkapan fasilitas, keamanan, kenyamanan } \\
\text { yang baik }\end{array}$ & X17 & & $\mathrm{V}$ \\
\hline
\end{tabular}




\section{Strategi Peningkatan dan Perbaikan}

Hasil analisis SEM dan IPA menjadi dasar manajemen hotel untuk melaksanakan upaya-upaya strategi operasional yang tepat dan efektif. Seperti halnya Chu \& Choi (2000) dari hasil analisis tersebut yang terlihat pada Tabel 6, maka manajemen dapat mulai melakukan perbaikan atribut yang mempunyai tingkat kepentingan di atas rata-rata, kinerja dibawah rata-rata dan mempunyai nilai pengaruh terhadap kepuasan yang besar menjadi prioritas, yaitu meliputi: (a) Tangible, yaitu kualitas kebersihan, kenyamanan dan ketersediaan perlengkapan ruang rapat, kualitas kebersihan, kenyamanan dan ketersediaan perlengkapan kamar dan kamar mandi, ketersediaaan fasilitas pendukung hotel; (b) Reliability, yaitu: kualitas pelayanan karyawan hotel dan harga sesuai dengan fasilitas yang didapat; (c) Responsiveness, yaitu kecepatan memenuhi permintaan; (d) Assurance, yaitu keramahan dan kesopanan karyawan baik.
Karena secara analisis SEM semua atribut mempunyai pengaruh yang signifikan, maka prioritas perbaikan dimulai atas dasar nilai kinerja yang paling rendah. Manajemen juga harus mempertahankan pada atribut yang kinerjanya sudah baik dan nilai kepentingannya tinggi. Pada institusi Pemerintah adalah, keramahan dan kesopanan karyawan baik, fasilitas hotel berjalan dengan baik, hotel berbintang mempunyai kelengkapan fasilitas, keamanan, Kenyamanan yang baik. Pada institusi Non-pemerintahan kinerja yang harus dipertahankan yaitu, kualitas penyajian, rasa dan variasi makanan \& minuman, kualitas penampilan dan ketrampilan karyawan, lokasi strategis, jaminan keamanan dan kenyamanan. Dengan demikian akan meningkatkan word of mouth konsumen yang berdasarkan hasil pernyataan responden menjadi kekuatan penyampaian informasi dari hotel

Intinya secara fisik hotel dilakukan perubahan interior, perbaikan yang rusak, pemeliharaan yang

Tabel 5. Hasil Analisis SEM dan Analisis IPA pada Atribut yang Signifikan

\begin{tabular}{|c|c|c|c|c|c|c|c|c|c|c|}
\hline \multirow[b]{3}{*}{ No. } & & \multirow[b]{3}{*}{ Atribut } & \multicolumn{4}{|c|}{ Pemerintah } & \multicolumn{4}{|c|}{ Non-pemerintah } \\
\hline & & & \multirow[b]{2}{*}{ Kuadran } & MIS & MPS & $\mathrm{LF}$ & \multirow[b]{2}{*}{ Kuadran } & MIS & \multirow{2}{*}{$\begin{array}{c}\text { MPS } \\
\text { Mean } \\
\text { Performance } \\
\text { Score }\end{array}$} & \multirow{2}{*}{$\begin{array}{c}\text { LF } \\
\text { Loading } \\
\text { Factor }\end{array}$} \\
\hline & & & & $\begin{array}{c}\text { Mean } \\
\text { Importance } \\
\text { Score }\end{array}$ & $\begin{array}{l}\text { Mean } \\
\text { Performance } \\
\text { Score }\end{array}$ & $\begin{array}{l}\text { Loading } \\
\text { Factor }\end{array}$ & & $\begin{array}{c}\text { Mean } \\
\text { Importance } \\
\text { Score }\end{array}$ & & \\
\hline $\mathbf{I}$ & \multicolumn{10}{|c|}{ Dimensi Tangible } \\
\hline 1 & $\mathrm{X} 1$ & $\begin{array}{l}\text { Kualitas kebersihan, kenyamanan dan ketersediaan } \\
\text { perlengkapan ruang rapat }\end{array}$ & \multirow{6}{*}{ Signifikan } & 5,35 & 5,54 & 0,73 & 1 & 5,87 & 5,71 & 0,78 \\
\hline 2 & $\mathrm{X} 2$ & $\begin{array}{l}\text { Kualitas kebersihan, kenyamanan dan ketersediaan } \\
\text { perlengkapan kamar dan kamar mandi }\end{array}$ & & 5,44 & 5,48 & 0,74 & 1 & 6,01 & 5,30 & 0,74 \\
\hline 3 & X3 & $\begin{array}{l}\text { Kualitas penyajian, rasa dan variasi makanan \& } \\
\text { minuman }\end{array}$ & & 5,35 & 5,56 & 0,82 & ॥ & 5,90 & 5,89 & 0,94 \\
\hline 4 & $\mathrm{X} 4$ & Kualitas penampilan dan ketrampilan karyawan & & 5,41 & 5,72 & 0,84 & II & 5,81 & 6,02 & 0,82 \\
\hline 5 & $\mathrm{X} 5$ & Ketersediaaan fasilitas pendukung hotel & & 5,26 & 5,58 & 0,87 & 1 & 5,84 & 5,66 & 0,84 \\
\hline 6 & $\mathrm{x} 6$ & Lokasi strategis & & 5,89 & 5,74 & 0,52 & II & 6,08 & 6,00 & 0,78 \\
\hline II & \multicolumn{10}{|c|}{ Dimensi Reliability } \\
\hline 7 & $\mathrm{X7}$ & Kualitas pelayanan karyawan hotel & \multirow{4}{*}{ Tidak } & 5,46 & 5,54 & 0,89 & 1 & 5,95 & 5,52 & 0,55 \\
\hline 8 & $\mathrm{x} 8$ & Harga sesuai dengan fasilitas yang didapat & & 5,42 & 5,54 & 0,89 & 1 & 5,88 & 5,78 & 1,00 \\
\hline 9 & X9 & Jaminan keamanan dan kenyamanan & & 5,35 & 5,58 & 0,91 & II & 5,86 & 6,19 & 0,99 \\
\hline 10 & $\mathrm{X} 10$ & Ketersediaan internet yang baik & & 4,97 & 5,42 & 0,80 & III & 4,92 & 6,03 & 1,00 \\
\hline III & \multicolumn{10}{|c|}{ Dimnesi Responsiveness } \\
\hline 11 & $\mathrm{X} 11$ & Kualitas ketanggapan karyawan & IV & 5,29 & 5,57 & 0,92 & III & 5,63 & 6,23 & 0,89 \\
\hline 12 & $\mathrm{x} 12$ & Kecepatan memenuhi permintaan & 1 & 5,54 & 5,58 & 0,94 & III & 5,56 & 5,97 & 1,00 \\
\hline 13 & $\mathrm{x} 13$ & Pengetahuan tentang produk hotel HSTH & IV & 5,11 & 5,45 & 0,93 & IV & 5,56 & 5,85 & 1,00 \\
\hline 14 & $\mathrm{X} 14$ & Kualitas pemecahan masalah & IV & 5,12 & 5,54 & 1,00 & III & 5,56 & 5,98 & 1,00 \\
\hline IV & \multicolumn{10}{|c|}{ Dimensi Assurance } \\
\hline 15 & $\mathrm{X} 15$ & Keramahan dan kesopanan karyawan baik & II & 5,51 & 5,64 & 1,00 & 1 & 6,09 & 5,66 & 0,70 \\
\hline 16 & $\mathrm{X} 16$ & Fasilitas hotel berjalan dengan baik & II & 5,38 & 5,63 & 1,00 & III & 5,75 & 6,04 & 0,90 \\
\hline 17 & $\mathrm{x} 17$ & $\begin{array}{l}\text { Hotel berbintang mempunyai kelengkapan fasilitas, } \\
\text { keamanan, kenyamanan yang baik }\end{array}$ & ॥ & 5,38 & 5,78 & 1,00 & IV & 5,70 & 5,82 & 0,91 \\
\hline 18 & $\mathrm{X} 18$ & Inisiatif karyawan baik & III & 5,29 & 5,67 & 1,30 & III & 5,71 & 6,05 & 1,02 \\
\hline $\mathbf{V}$ & \multicolumn{10}{|c|}{ Dimensi Empathy } \\
\hline 19 & $\mathrm{X} 19$ & Peka akan keinginan tamu & IV & 5,26 & 5,60 & 1,00 & \multirow{3}{*}{$\begin{array}{c}\text { Tidak } \\
\text {-signifikan- }\end{array}$} & 5,79 & 5,94 & 1,00 \\
\hline 20 & $\mathrm{x} 20$ & $\begin{array}{l}\text { Tanggap dan menyiapkan kebutuhan tamu sebelum } \\
\text { diminta }\end{array}$ & III & 5,17 & 5,71 & 0,95 & & 5,87 & 5,75 & 1,00 \\
\hline 21 & $\mathrm{X} 21$ & $\begin{array}{l}\text { Fleksibilitas karyawan dalam penanganan masalah } \\
\text { tamu }\end{array}$ & III & 5,21 & 5,62 & $\overline{1,00}$ & & 5,79 & 5,99 & 0,98 \\
\hline$*$ & \multicolumn{3}{|c|}{ Average } & 5,30 & 5,62 & & & 5,76 & 5,87 & \\
\hline
\end{tabular}


baik terhadap ruang rapat, kamar dan semua peralatan pendukungnya, Secara non fisik dilakukan pelatihan, peningkat kualitas kinerja karyawan, supervisi dan pengawasan yang intensif.

\section{SIMPULAN DAN SARAN}

Penelitian ini membuktikan hubungan yang positif antara kepuasan dan loyalitas, sehingga peningkatan kepuasan akan mendorong peningkatan positif pada rekomendasi konsumen dan kesediaan beracara kembali, seperti yang dikatakan Griffin (1995) dan Olson (1993). Hasil penelitian pada institusi Pemerintah di dapat dimensi responsiveness, empathy dan assurance yang berpengaruh pada kepuasan. Dimensi angible dan reliability dianggap tidak berpengaruh pada kepuasan. Dari institusiNonpemerintahdidapat hasil dimensi tangible, reliability, responsiveness dan assurance yang berpengaruh signifikan pada kepuasan, sedangkan dimensi empathy tidak berpengaruh signifikan pada kepuasan.

Memperbaiki kinerja pada atribut yang signifikan pengaruhnya pada kepuasan dan mempunyai nilai tingkat kepentingan diatas rata-rata serta kinerja dibawah rata-rata, yaitu: (a) Dimensi Tangible, yaitu kualitas kebersihan, kenyamanan dan ketersediaan perlengkapan ruang rapat, kualitas kebersihan, kenyamanan dan ketersediaan perlengkapan kamar dan kamar mandi, ketersediaaan fasilitas pendukung hotel. Perbaikan dilakukan dengan cara memperbaiki sarana fisik dan desain interior yang sudah lama. Memelihara peralatan, sehingga dapat berfungsi dengan baik dan mengganti yang sudah rusak. Perbaikan tingkat kebersihan dilakukan dengan cara pelatihan sumber daya manusia untuk melakukan pekerjaan sesuai prosedur dan supervisi serta pengawasan yang intensif. (b) Dimensi Reliability, yaitu: kualitas pelayanan karyawan hotel dan harga sesuai dengan fasilitas yang didapat, harga sesuai dengan fasilitas yang didapat. (c) Dimensi Responsiveness, yaitu kecepatan memenuhi permintaan dan dimensi Assurance, yaitu keramahan dan kesopanan karyawan baik. Perbaikan dengan cara pelatihan sumber daya manusia, pengawasan dan supervisi yang lebih baik. Meningkatkan kualitas pelatihan yang lebih mudah dimengerti dan dipahami.

Menjaga kualitas kinerja atribut yang sudah baik yang mempunyai nilai kepentingan dan kinerja juga tinggi. Atribut-atribut yang harus dijaga kinerjanya yang sudah baik pada institusi Pemerintah adalah, keramahan dan kesopanan karyawan baik, fasilitas hotel berjalan dengan baik, hotel berbintang mempunyai kelengkapan fasilitas, keamanan, kenyamanan yang baik. Pada institusi Non-pemerintah kinerja yang harus dipertahankan yaitu, kualitas penyajian, rasa dan variasi makanan \& minuman, kualitas penampilan dan ketrampilan karyawan, lokasi strategis, jaminan keamanan dan kenyamanan.

Sesuai hasil analisis SEM bahwa dimensi assurance adalah faktor terbesar tingkat kepentingannya padapenilaian konsumen untuk usaha jasa. Sesuai konsep dasar jasa pelayanan yaitu kecepatan, kebersihan dan kenyamanan, maka meningkatkan kualitas kinerja sumber daya manusia adalah hal utama yang harus dilakukan, pelatihan karyawan sesuai dengan standard operating procedure (SOP) dan pengawasan serta supervisi yang baik merupakan hal yang sangat penting untuk menunjang perbaikan kinerja.

Strategi manajemen dapat lebih terarah dalam menghadapi konsumen yang dilayani dengan dasar kepentingan atribut dari harapan konsumen serta atribut dan dimensi yang berpengaruh signifikan pada kepuasan dan loyalitas.

Hasil penelitian ini dapat menjadi acuan dalam menjalankan operasi hotel untuk melayani semua institusi dalam melaksanakan aktivitas MICE, sehingga manajemen hotel dapat lebih terarah dan tepat dalam memberikan layanannya. Perbaikan pada atribut yang masuk dalam dimensi tangible segera dilakukan. Perbaikan dapat menggunakan jasa konsultan perencanaan interior agar dapat memberikan hasil yang tepat dan optimal. Perbaikan kualitas pelayanan juga dapat dilakukan pelatihan menggunakan jasa konsultan untuk membuka wawasan tentang pelayanan yang lebih baik.

Penelitian dapat dilanjutkan dengan mencari faktor-faktor lain selain kepuasan dan loyalitas yang berpengaruh pada peningkatan kinerja hotel dalam memberikan layanan jasa kepada konsumen seperti tinjauan dari sisi harga yang menjadi salah satu faktor pengaruh yang signifikan dalam penelitian ini, serta sumber daya manusia dan kinerja, yang kontribusinya sangat besar dalam usaha jasa pelayanan untuk memberikan kepuasan konsumen

\section{DAFTAR REFERENSI}

Castle, D. J. 2008. Comparing Expectations and Perceptions of Service Quality for Special Event Entertainment Services, Ph.D, Northcentral University Arizona.

Chu, R. K. S. \& Choi, T. 2000. An Importance Performance Analysis of Hotel Selection Factors in the Hongkong Hotel Industry: A Comparison of Business and Leisure Travellers, Tourism Management, 21(4): 363-377.

Dixon, W. \& Massey, J. 1991. Pengantar Analisis Statistik, Yogyakarta: Gajah Mada Press. 
Eboli, L. \& Mazzulla, G. 2009. A New Customer Satisfaction Index for Evaluating Transit Service Quality, Journal of Public Transportation, 12(3): 21-37.

Griffin, J. 1995. Customer Loyalty, How to Earn It, How to Keep It, USA: Jossey-Bass Inc.

Markovic, S. 2010. Customer Satisfaction and Customer Loyalty in Hotel Settings: An Empirical Analysis, Journal of Tourism and Hospitality Management, Conference Proceedings.

Martilla, J. A. \& James, J. C. 1977. Importance-Performance Analysis, Journal of Marketing, 41(1): 77-79.
Parasuraman, V., Zeithaml V. A. \& Berry, L. L. 1988. SERVQUAL: A Multiple-Item Scale for Measuring Consumer Perception of Service Quality. Journal of Retailing, 64(1): 12-40.

Simamora, B. 2002. Panduan Riset Perilaku Konsumen, Jakarta: Gramedia Pustaka Utama.

Wijanto, S. H. 2008. Structural Equation Modelling dengan Lisrel 8.8: Konsep dan Tutorial, Yogyakarta: Graha Ilmu.

Olson, P. 1993. Consumer Behavior and Marketing Strategy, Third Edition, Boston: Richard D. Irwin Inc. 